\title{
ANALISIS MATERI KETERAMPILAN BERBICARA DASAR BAHASA MANDARIN
}

\author{
Ayu Trihardini, M.A., Aprilia Ruby Wikarti, M.A., Arief Rifki Fadilla \\ Program Studi Pendidikan Bahasa Mandarin \\ Fakultas Bahasa dan Seni \\ Universitas Negeri Jakarta
}

\begin{abstract}
Abstrak
Program Studi Pendidikan Bahasa Mandarin (PSPBM) UNJ sebagai program studi yang berkomitmen untuk terus melakukan upaya-upaya perbaikan serta pengembangan kualitas pengajaran bahasa Mandarin di Indonesia pada umumnya, memutuskan untuk mengembangkan buku ajar keterampilan berbahasanya sendiri. Ketiadaan buku ajar berseri yang dapat mengakomodir kebutuhan pembelajaran bahasa Mandarin merupakan hal mendesak. Pengembangan buku ajar keterampilan berbicara memerlukan pengetahuan mengenai buku ajar seperti apa yang dibutuhkan. Dengan demikian, PSPBM melakukan penelitian berbasis Research and Development yang terdiri dari tiga tahap, yaitu: 1) Tahun 2017: Analisis Kebutuhan; 2) Tahun 2018: Analisis materi; dan terakhir tahap 3) Penyusunan buku ajar.

Tulisan ini membahas penelitian tahap ke dua. Kegiatan analisis materi memperhatikan hal-hal berikut: 1) Dokumen kurikulum PSPBM FBS UNJ, mencakupi profil lulusan, deskripsi mata kuliah, CPMK Menyimak dan Berbicara Dasar I-IV; 2) Kesesuaian materi dengan deskripsi level pada CEFR; 3) Hasil penelitian sebelumnya (Analisis Kebutuhan); 4) Teori dan hasil penelitian terkait analisis materi keterampilan berbicara. Melalui penelitian analisis materi dan penyusunan ragangan, dapat diketahui materi percakapan apa yang diperlukan serta sesuai bagi buku teks untuk keperluan mata kuliah Menyimak dan Berbicara Dasar di PSPBM FBS UNJ. Selain itu, PSPBM mendapatkan produk berupa materi percakapan dan ragangan yang diperlukan untuk kebutuhan penyusunan buku ajar Menyimak dan Berbicara Dasar semester I hingga IV. Hasil penelitian selanjutnya dapat menjadi landasan dalam penelitian tahap selanjutnya yaitu penelitian pengembangan penyusunan buku ajar mata kuliah Menyimak dan Berbicara Dasar.
\end{abstract}

Kata Kunci: Analisis Materi, Keterampilan Berbicara, Bahasa Mandarin

\section{A. PENDAHULUAN}

Keberagaman sistem pendidikan antar institusi di setiap negara, dengan keberagaman identitas serta budaya merupakan sebuah keniscayaan. Sementara itu, hadirnya masa dimana mobilitas dan komunikasi internasional sangat intens menuntut bukan hanya kompetensi berbahasa asing yang mumpuni, namun juga adanya acuan pengukuran terhadap kompetensi tersebut. PSPBM sebagai bagian dari FBS UNJ menggunakan Common European Framework of Reference for Language (CEFR) sebagai acuan pengukuran kompetensi kebahasaan, yang juga merupakan rujukan bagi rumusan kurikulum prodi-prodi bahasa di lingkungan FBS.

Agar mencapai kompetensi berbahasa yang diharapkan, diperlukan bahan ajar yang relevan. Saat ini, buku keterampilan berbicara yang digunakan berbagai program studi kependidikan Mandarin di Indonesia tidak seluruhnya diperuntukkan secara khusus untuk melatih kompetensi berbicara, sehingga capaian pembelajaran yang berintikan pada komunikasi praktis, dinilai tidak tercapai dengan maksimal. Ketiadaan buku teks keterampilan berbicara bahasa Mandarin yang seharusnya digunakan secara berseri dengan keterampilan berbahasa lainnya menjadi muara adanya kebutuhan pengembangan buku ajar mata kuliah keterampilan berbicara. PSPBM FBS UNJ sebagai program studi yang 
berkomitmen untuk terus melakukan upaya-upaya perbaikan serta pengembangan kualitas pengajaran bahasa Mandarin di Indonesia, memutuskan untuk mengembangkan buku ajar keterampilan berbahasa Mandarinnya sendiri. Pengembangan buku ajar keterampilan berbicara memerlukan pengetahuan mengenai buku ajar seperti apa yang dibutuhkan. Dengan demikian, perlu dilakukan sebuah penelitian analisis materi. Tulisan ini akan membahas mengenai materi apa yang perlu ada dalam buku teks mata kuliah keterampilan berbicara bahasa Mandarin tingkat dasar, agar sesuai dengan kompetensi yang ditetapkan.

Pembahasan mengenai buku teks dalam kaitannya dengan pembelajaran bahasa disampaikan oleh Richards. Richards (2001:254) menyatakan buku teks digunakan dengan cara berbeda dalam pembelajaran bahasa. Di dalam buku teks keterampilan berbicara perlu memiliki teks atau dialog untuk latihan dan diskusi untuk peserta didik.

Mengutip Cai (2009:160), yang dilatih dalam buku ajar keterampilan berbicara adalah kemampuan komunikasi lisan dalam situasi sosial yang umum. Cai membagi buku ajar keterampilan berbicara bahasa Mandarin menjadi beberapa jenis:

1. Berdasarkan tingkat kemahiran

Umumnya terdiri dari 3 tingkatan: tingkat dasar, tingkat menengah, dan tingkat mahir. Ada pula yang terdiri dari 5 tingkatan.

2. Berdasarkan waktu pembelajaran

1) Buku ajar untuk durasi panjang

2) Buku ajar untuk durasi pendek (les, program musim panas)

3. Berdasarkan usia peserta didik

1) Buku ajar untuk peserta didik berusia dewasa

2) Buku ajar untuk peserta didik berusia anak-anak

4. Berdasarkan asal negara peserta didik

1) Buku ajar untuk peserta didik dari banyak negara

Buku ajar dapat digunakan bagi peserta didik yang bahasa ibunya beragam, efektif digunakan pada kelas pengajaran bahasa dengan peserta didik dari beberapa negara berbeda.

2) Buku ajar untuk peserta didik dari negara tertentu

Buku ajar bersifat spesifik untuk peserta didik suatu negara, sehingga dapat melalui analisis kontrastif kedua bahasa dan budaya; menyusun buku ajar berdasarkan karakteristik dan kesulitan fonetik, kosa kata, tata bahasa, penggunaan bahasa dan kebudayaan. Buku ajar jenis ini efektif digunakan pada kelas pengajaran bahasa Mandarin yang seluruh peserta didiknya pengguna bahasa tertentu atau pemelajar yang mempelajari bahasa Mandarin di lingkungan bahasa ibunya.

5. Berdasarkan prinsip penyusunan buku ajar

1) Buku ajar berdasarkan fungsi

2) Buku ajar berdasarkan tema

3) Buku ajar berdasarkan situasi, tema, fungsi

6. Berdasarkan lingkungan bahasa

1) Buku ajar bagi peserta didik yang belajar di lingkungan berbahasa Mandarin

2) Buku ajar bagi peserta didik yang belajar di lingkungan bahasanya sendiri

Berdasarkan pada klasifikasi Cai di atas, maka penelitian ini merupakan penelitian yang dilakukan untuk membahas materi apa yang diperlukan serta sesuai bagi buku ajar keterampilan berbicara bahasa Mandarin dalam pengajaran bahasa berdurasi panjang bagi 
peserta didik dewasa berbahasa ibu bahasa Indonesia yang belajar di lingkungan bahasanya sendiri.

\section{B. METODE PENELITIAN}

Dilihat dari sisi pendidik, materi pembelajaran harus dibentuk dan disampaikan kembali dalam bentuk kegiatan pembelajaran. Sedangkan dilihat dari sisi peserta didik, materi harus dipelajari dalam rangka mencapai standar kompetensi. Dalam mendesain materi pembelajaran diperlukan analisis pembelajaran, umumnya menggunakan model 'Dick and Carey'. Menurut model Dick dan Carey, tujuan pembelajaran yang telah diidentifikasi perlu dianalisis untuk menemukenali keterampilan-keterampilan bawahan (sub ordinate skills) yang harus dikuasai peserta didik dan langkah-langkah prosedural bawaan yang harus diikuti peserta didik untuk dapat belajar. Analisis pembelajaran bertujuan untuk menentukan keterampilan-keterampilan yang akan dijangkau oleh tujuan pembelajaran, serta memungkinkan untuk membuat keputusan yang diperlukan dalam urutan mengajar.

Materi merupakan bagian tak terpisahkan dari perencanaan kegiatan pembelajaran, sehingga peserta didik memenuhi standar kompetensi berupa pengetahuan, keterampilan, dan sikap tertentu yang ditetapkan. Standar kompetensi harus sesuai dengan capaian pembelajaran dalam kurikulum. Pada rangkaian mata kuliah Menyimak dan Berbicara Dasar di PSPBM UNJ, keterampilan yang ingin dicapai secara umum adalah kemampuan berkomunikasi lisan, maka materi-materi dalam buku ajar nantinya harus mendukung tercapainya kompetensi dan tujuan pembelajaran melalui topik dan kegiatan pembelajaran yang menunjang, penguasaan unsur kebahasaan dalam berkomunikasi, pengetahuan seni budaya Cina, dan lain sebagainya.

\section{PEMBAHASAN}

Berdasarkan hasil penelitian Trihardini dan Wikarti mengenai Analisis Kebutuhan Pengembangan Buku ajar Mata Kuliah Percakapan di tahun 2017, buku ajar mata kuliah keterampilan berbicara yang digunakan di prodi-prodi kependidikan bahasa Mandarin di Indonesia berupa: (1) buku keterampilan berbicara bahasa Mandarin yang diambil dari seri buku berbeda dengan keterampilan berbahasa lainnya. Buku keterampilan menyimak, membaca, menulis merupakan buku dari seri yang sama, hanya buku keterampilan berbicara yang diambil terpisah. Hal ini disebabkan ketidaklengkapan seri buku keterampilan berbahasa Mandarin yang digunakan; (2) buku keterampilan berbahasa Mandarin yang tidak secara khusus diperuntukkan untuk keterampilan berbicara.

Temuan penelitian menjadi hal yang sangat menarik, karena bertentangan dengan pendapat Eddy (2005) dalam Silaban (2010) yaitu isi materi buku pelajaran harus relevan dengan tuntutan kurikulum yang berlaku serta harus relevan dengan kompetensi yang harus dimiliki oleh lulusan tingkat pendidikan tertentu.

PSPBM UNJ dalam kurikulumnya, mendistribusikan capaian level CEFR per semester. Dengan mempertimbangkan standar kelulusan CEFR level B2, maka mata kuliah keterampilan berbahasa Mandarin pada kurikulum PSPBM FBS UNJ diberikan dalam 7 semester dengan pembagian sebagai berikut:

Tabel 1. Penguasaan Level CEFR dalam Mata Kuliah Keterampilan Berbahasa PSPBM UNJ

\begin{tabular}{|c|c|c|}
\hline $\begin{array}{c}\text { Semester } \\
\text { ke- }\end{array}$ & Nama Mata Kuliah & Capaian Level CEFR \\
\hline 1 & $\bullet$ Menyimak dan Berbicara Dasar I & A1 \\
\hline
\end{tabular}




\begin{tabular}{|c|l|c|}
\hline & $\begin{array}{l}\text { - Membaca dan Menulis Dasar I } \\
\text { - Tata Bahasa I }\end{array}$ & \\
\hline 2 & $\begin{array}{l}\text { - Menyimak dan Berbicara Dasar II } \\
\text { - Membaca dan Menulis Dasar II } \\
\text { - Tata Bahasa II }\end{array}$ & \\
\hline 3 & $\begin{array}{l}\text { - Menyimak dan Berbicara Dasar III } \\
\text { - Membaca dan Menulis Dasar III } \\
\text { - Tata Bahasa III }\end{array}$ & B1 \\
\hline 4 & $\begin{array}{l}\text { - Menyimak dan Berbicara Dasar IV } \\
\text { - Membaca dan Menulis Dasar IV } \\
\text { - Tata Bahasa IV }\end{array}$ & B1 \\
\hline 5 & $\begin{array}{l}\text { - Menyimak dan Berbicara Lanjut I } \\
\text { - Membaca dan Menulis Lanjut I }\end{array}$ & B2 \\
\hline 6 & $\begin{array}{l}\text { - Menyimak dan Berbicara Lanjut II } \\
\text { - Membaca dan Menulis Lanjut II }\end{array}$ & B2 \\
\hline 7 & - Audio Visual Bahasa Mandarin & B2 \\
\hline
\end{tabular}

Kompetensi dan tujuan pembelajaran yang telah tercantum dalam Capaian Pembelajaran Mata Kuliah (CPMK) Menyimak dan Berbicara Dasar I-IV dan berkaitan dengan standar CEFR perlu dianalisis. Berikut merupakan hal-hal yang dilakukan dalam kegiatan analisis materi pada penelitian ini:

1. Mengidentifikasi aspek-aspek yang terdapat dalam standar kompetensi yang harus dipelajari atau dikuasai peserta didik. Setiap aspek standar kompetensi memerlukan jenis materi pembelajaran yang berbeda.

2. Mengidentifikasi jenis-jenis materi pembelajaran

Jenis materi berorientasi pada:

(1) Hierarki kebutuhan peserta didik

(2) Perkembangan peserta didik. Peserta didik adalah generasi $Z$ yang merupakan native terhadap teknologi. Menurut Trihardini (2019), bagi generasi $Z$ yang saat ini mengalami revolusi industri 4.0 dan akan ikut berpartisipasi dalam masa bonus demografi Indonesia, penyampaian pembelajaran melalui media yang berorientasi pada literasi baru sangat dibutuhkan.

(3) Absolenscence, mencakupi validitas dan signifikansi isi kurikulum agar relevan dengan perkembangan ilmu pengetahuan dan teknologi. Pada era revolusi industri yang disruptive seperti dewasa ini, kurikulum berorientasi pada literasi baru sehingga mampu membekali lulusan dengan kompetensi-kompetensi yang diperlukan di masa mendatang, dalam kemungkinan menekuni profesi-profesi yang saat ini belum ada.

(4) Konsistensi materi, yakni adanya kesesuaian antara jumlah kompetensi dengan jumlah materi yang diajarkan

3. Memilih jenis materi yang sesuai dengan standar kompetensi yang harus dikuasai peserta didik.

\section{Keterampilan Berbicara Bahasa Mandarin}

Kemampuan berbahasa seseorang merupakan suatu kompetensi yang terintegrasi. Menyimak dan membaca merupakan kegiatan reseptif, sementara berbicara dan menulis merupakan kegiatan produktif dalam hal mengemukakan gagasan. Dalam hal bercakap- 
cakap, keterampilan menyimak dan berbicara tidak terpisahkan. Hubungan antar keterampilan berbahasa menyimak, berbicara, membaca dan menulis dapat dilihat pada:

Tabel 2. Hubungan Antar Keterampilan Berbahasa (diambil dari Tarigan, 2013: 2)

\begin{tabular}{|c|c|c|c|c|}
\hline $\begin{array}{l}\text { Langsung } \\
\text { Apresiatif } \\
\text { Reseptif } \\
\text { Fungsional }\end{array}$ & Menyimak & $\begin{array}{l}\text { Komunikasi } \\
\text { tatap muka }\end{array}$ & Berbicara & $\begin{array}{l}\text { Langsung } \\
\text { Produktif } \\
\text { Ekspresif }\end{array}$ \\
\hline & & $\begin{array}{l}\text { Keterampilan } \\
\text { berbahasa }\end{array}$ & & \\
\hline $\begin{array}{l}\text { Tak langsung } \\
\text { Produktif } \\
\text { Ekspresif }\end{array}$ & Menulis & $\begin{array}{l}\text { Komunikasi } \\
\text { tidak tatap muka }\end{array}$ & Membaca & $\begin{array}{l}\text { Tak langsung } \\
\text { Apresiatif } \\
\text { Reseptif } \\
\text { Fungsional }\end{array}$ \\
\hline
\end{tabular}

Berdasarkan tabel di atas diketahui bahwa seluruh keterampilan berbahasa saling mempengaruhi satu sama lain, keterampilan berbicara dapat diperoleh karena menguasai keterampilan menyimak, begitupun keterampilan menulis dapat diperoleh karena menguasai keterampilan membaca. Seluruh keterampilan hanya dapat dikuasai melalui praktik dan latihan, terutama dalam konteks berbahasa asing.

Fungsi bahasa sebagai alat komunikasi, nampak pada keterampilan berbicara. Tarigan (2013) mengungkapkan, berbicara adalah kemampuan mengucapkan bunyi-bunyi artikulasi atau kata-kata untuk mengekspresikan, menyatakan atau menyampaikan pikiran, gagasan atau perasaan. Dengan demikan, berbicara bukan hanya pembunyian ujaran oleh alat ucap, sehingga pembelajaran keterampilan berbicara tidak terbatas pada imitasi bunyi, intonasi, namun juga pengetahuan kosa kata, penggunaan kata-kata, perangkaian pola-pola kalimat, dan pengekspresian gagasan. Bahasa Mandarin merupakan bahasa tonal, namun pengajaran keterampilan berbicara bahasa Mandarin juga harus mencakupi hal-hal tersebut di atas. Zhao (2008) memaparkan, keterampilan berbicara bahasa Mandarin dilatih melalui kemampuan lisan, mencakupi pengetahuan fonologi, kemampuan memilih kata dan merangkainya menjadi kalimat, kemampuan mengungkapkan gagasan serta kemampuan menggunakan dalam konteks dan lain sebagainya.

Menurut Zhang Xiaotao (2008) pengajaran keterampilan berbicara bahasa Mandarin perlu memerhatikan beberapa hal, yaitu: (1) pengajaran menekankan pada kebutuhan komunikasi, sehingga peserta didik menguasai ragam lisan melalui proses komunikasi; (2) praktik bercakap-cakap dapat berupa gabungan latihan per unit dan latihan konteks penggunaan, untuk melatih kemampuan berkomunikasi secara lebih menyeluruh; (3) pengajaran mementingkan latihan penggunaan, demi meningkatkan minat dan motivasi peserta didik. Zhang berpendapat pengajaran keterampilan berbicara bahasa Mandarin masih belum mempunyai teori pengajaran yang komprehensif dan sistematis. Teori yang ada saat ini belum sesuai dengan perkembangan pengajaran keterampilan berbicara serta kebutuhan praktis terhadap keterampilan tersebut yang meningkat pesat.

\section{Keterampilan Berbicara dalam CEFR}

Common European Framework of Reference for Languages (CEFR) dapat diartikan sebagai kerangka acuan umum Eropa untuk pembelajaran bahasa. Dewasa ini, CEFR menjadi kerangka dasar untuk penyusunan silabus, pedoman kurikulum, ujian, buku teks dan lain- 
lain tidak terbatas di daratan Eropa. CEFR merupakan standar acuan yang digunakan dalam pembelajaran bahasa asing di FBS UNJ. CEFR selain menjabarkan capaian-capaian pengetahuan, keterampilan berbahasa serta konteks budaya yang harus dikuasai oleh pemelajar, juga standar tingkatan penguasaan kemampuan bahasa asing yang sedang dipelajari. Menurut standar tingkatan penguasaan, CEFR mengklasifikasikan peserta didik menjadi:

1. Basic user (tingkat dasar)

A1 Breakthrough: Prapemula

A2 Waystage: Pemula

2. Independent user (tingkat mandiri)

B1 Threshold: Pramadya

B2 Vantage: Madya

3. Proficient user (tingkat mahir)

C1 Effective Operational Proficiency: Pralanjut

C2 Mastery: Lanjut

Keterampilan berbicara atau speaking dalam CEFR mempertimbangkan kompetensi linguistik, pragmatik, dan sosiolinguistik. Oleh sebab itu, keterampilan berbicara terbagi menjadi berbicara sebagai interaksi dan sebagai produksi. Paparan mengenai keterampilan berbicara level A1 hingga B1 dapat dilihat pada tabel:

Tabel 3. Penjabaran terhadap Keterampilan Berbicara pada CEFR

\begin{tabular}{|c|c|c|c|}
\hline & A1 & $A 2$ & B1 \\
\hline $\begin{array}{l}\text { Berbicara } \\
\text { sebagai } \\
\text { aktivitas } \\
\text { interaksi }\end{array}$ & $\begin{array}{l}\text { Saya dapat } \\
\text { berinteraksi dengan } \\
\text { cara sederhana, orang } \\
\text { lain mengulang ujaran } \\
\text { dengan lebih pelan } \\
\text { dan membantu saya } \\
\text { memformulasikan apa } \\
\text { yang akan saya } \\
\text { ujarkan. Saya dapat } \\
\text { bertanya } \\
\text { menjawab pertanyaan } \\
\text { sederhana dalam area } \\
\text { kebutuhan sederhana } \\
\text { atau topik-topik } \\
\text { umum. }\end{array}$ & 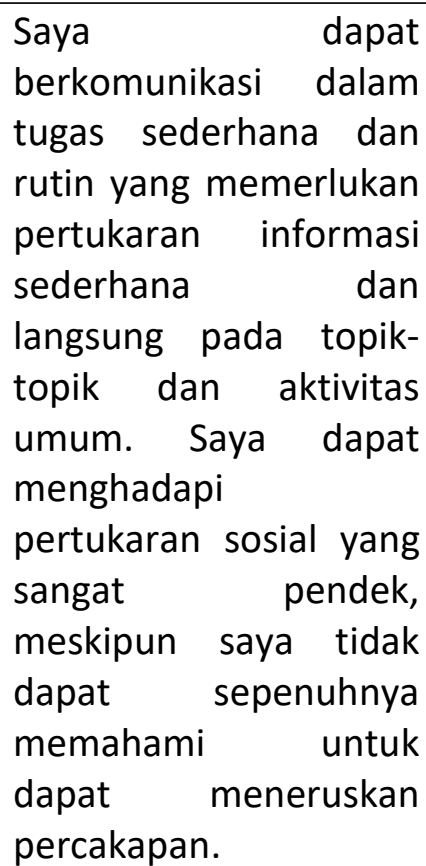 & $\begin{array}{l}\text { Saya dapat menghadapi } \\
\text { hampir seluruh situasi } \\
\text { yang mungkin timbul } \\
\text { ketika saya melakukan } \\
\text { perjalanan ke daerah } \\
\text { tempat bahasa target. } \\
\text { Saya dapat bercakap- } \\
\text { cakap tanpa persiapan } \\
\text { pada topik-topik umum, } \\
\text { peminatan individu } \\
\text { ataupun yang } \\
\text { berhubungan dengan } \\
\text { kehidupan sehari-hari } \\
\text { (misalnya keluarga, hobi, } \\
\text { pekerjaan, perjalanan } \\
\text { dan kejadian tertentu). }\end{array}$ \\
\hline $\begin{array}{l}\text { Berbicara } \\
\text { sebagai } \\
\text { aktivitas } \\
\text { produksi }\end{array}$ & $\begin{array}{lr}\text { Saya } & \text { dapat } \\
\text { menggunakan frasa } \\
\text { dan kalimat untuk } \\
\text { mendeskripsikan } \\
\text { dimana saya tinggal } \\
\text { dan orang-orang yang }\end{array}$ & $\begin{array}{lr}\text { Saya } & \text { dapat } \\
\text { menggunakan } & \\
\text { gabungan frasa dan } \\
\text { kalimat rantuk } \\
\text { mendeskripsikan dalam } \\
\text { bentuk sederhana }\end{array}$ & $\begin{array}{l}\text { Saya dapat menyambung } \\
\text { frasa-frasa } \\
\text { sederhana } \\
\text { mendeskripsikan } \\
\begin{array}{l}\text { pengalaman } \\
\text { kejadian, mimpi, harapan }\end{array}\end{array}$ \\
\hline
\end{tabular}


Jurnal Cakrawala Mandarin

Asosiasi Program Studi Mandarin Indonesia

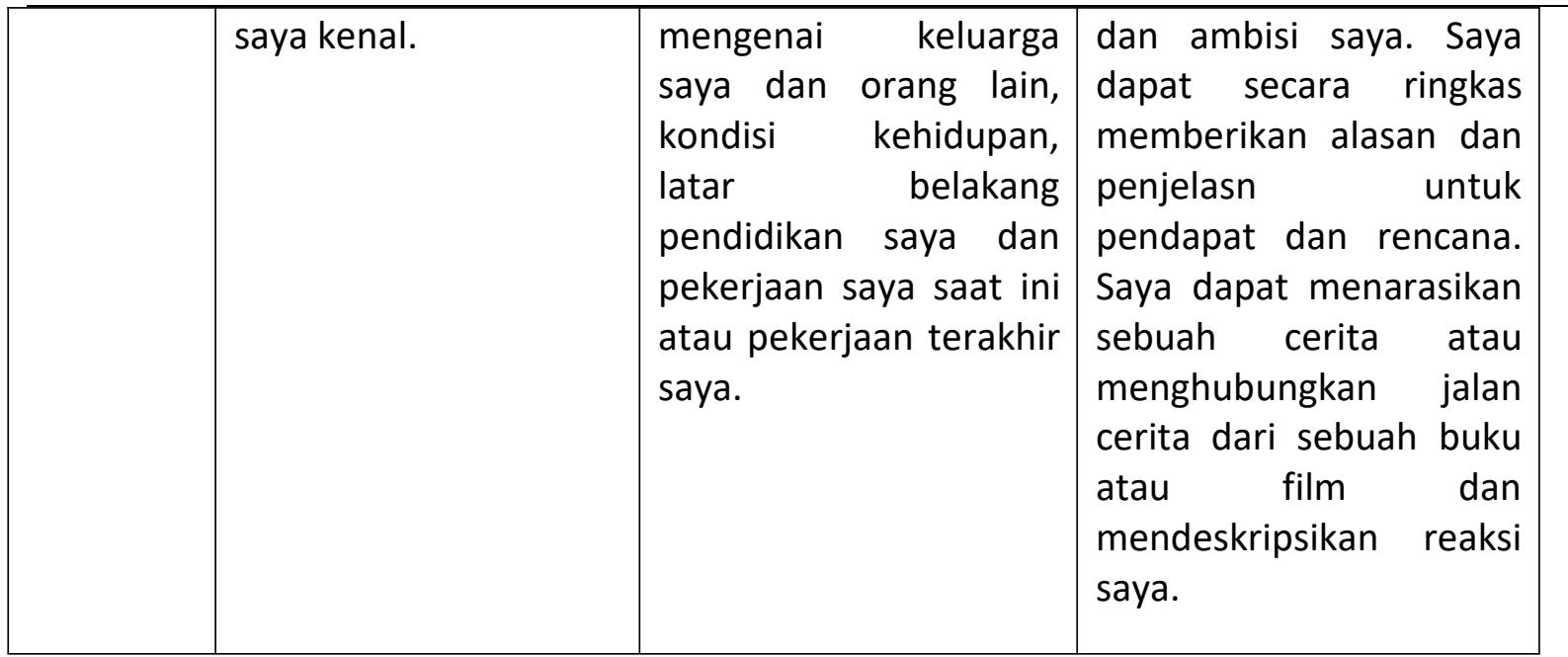

Berbicara sebagai aktivitas produksi, mencakupi kegiatan membaca lantang teks tertulis, berbicara berdasarkan catatan atau teks tertulis atau bagan visual berupa diagram, gambar, tabel dan lain sebagainya. CEFR menyediakan skala ilustratif untuk setiap level produksi bicara, monolog yang mendeskripsikan pengalaman, monolog dalam kasus tertentu (misalnya debat), pengumuman publik, serta berbicara untuk audiens tertentu.

Berbicara sebagai aktivitas interaksi, sesungguhnya menghubungkan antara kemampuan reseptif dan produktif. Kegiatan yang tercakup yaitu transaksi, percakapan sehari-hari, diskusi informal dan formal, debat, wawancara, negosiasi, membuat rencana, kerja sama praktis yang berorientasi pada hasil. CEFR menyediakan skala ilustratif untuk setiap level interaksi bicara, memahami penutur jati, percakapan, diskusi informal, diskusi dan pertemuan formal, kerja sama praktis yang berorientasi pada hasil, transaksi pemerolehan barang dan jasa, pertukaran informasi, mewawancara dan diwawancara.

Peneliti membatasi acuan CEFR hingga B1, disebabkan penelitian ini hanya akan melakukan analisis materi keterampilan berbicara tingkat dasar yang akan digunakan pada mata kuliah Menyimak dan Berbicara Dasar I-IV.

\section{Keterampilan Berbicara dalam HSK}

Berdasarkan tujuan penyelenggaran tes, Heaton (1988) mengklasifikasikan tes menjadi 4 jenis: (1) tes hasil belajar (achievement test), (2) tes penguasaan (proficiency test), (3) tes bakat (aptitude test), dan (4) tes diagnostic (diagnostic test). Kemudian Brown (2004) menambahkan jenis yang ke lima yaitu tes penempatan (placement test).

Dilihat dari kategorisasi tersebut, HSK tergolong dalam tes penguasaan, yaitu tes untuk menguji seberapa baik kompetensi seseorang menggunakan bahasa Mandarin. HSK adalah tes kompetensi pertama dan juga satu-satunya di RRT untuk mengukur level kemampuan bahasa Mandarin seorang peserta didik asing. Materi yang diujikan pada tes HSK terkait dalam 2 kelompok besar: (1) mencakupi 4 keterampilan berbahasa yaitu keterampilan menyimak, berbicara, membaca dan menulis, (2) mencakupi pengetahuan kebahasaan yaitu tata bunyi, kosa kata, tata bahasa, aksara Han dan lain sebagainya (Zhang, 2006: 252).

Jabaran mengenai jumlah kosa kata, kompetensi-kompetensi pada HSK yang ditetapkan Hanban RRT akan menjadi butir instrumen kesesuaian materi percakapan dengan HSK yang disusun oleh peneliti. 
Berkaitan dengan keterampilan berbicara, terdapat tes kompetensi untuk mengukur level kemampuan oral berbahasa Mandarin yaitu HSKK. HSKK terbagi atas 3 level, yaitu HSKK dasar/primary level, HSKK menengah/intermediate level dan HSKK mahir/advanced level. Hubungan pembagian level HSKK dengan level HSK dapat dilihat pada tabel berikut:

Tabel 4. Hubungan Antara Level HSK dan Level HSKK

\begin{tabular}{|l|l|l|}
\hline HSKK & HSK & Jumlah penguasaan kosa kata \\
\hline \multirow{3}{*}{ HSKK Mahir } & HSK 6 & Sekitar 3000 \\
\cline { 2 - 2 } & HSK 5 & \\
\hline \multirow{2}{*}{ HSKK Menengah } & HSK 4 & Sekitar 900 \\
\cline { 2 - 2 } & HSK 3 & \\
\hline \multirow{2}{*}{ HSKK Dasar } & HSK 2 & Sekitar 200 \\
\cline { 2 - 2 } & HSK 1 & \\
\hline
\end{tabular}

Peserta yang melampaui HSKK dasar dapat mengerti dan menggunakan bahasa Mandarin untuk mengungkapkan topik pembicaraan sehari-hari yang familiar, dalam memenuhi kebutuhan komunikasi mendasar. Peserta yang melampaui HSKK menengah dapat mengerti dan cukup fasih menggunakan bahasa Mandarin untuk berkomunikasi secara lisan dengan penutur jati bahasa Mandarin. Peserta yang melampaui HSKK mahir dapat mengerti dan fasih menggunakan bahasa Mandarin untuk mengungkapkan pendapat sendiri secara lisan. Penjelasan mengenai HSKK dari Hanban masih kurang terperinci, begitupun dengan buku latihan soal HSKK yang belum beredar bebas, sehingga meskipun HSKK adalah tes kemampuan oral berbahasa Mandarin namun tidak dapat dijadikan satusatunya acuan dalam penelitian ini.

\section{Materi-materi Keterampilan Berbicara Tingkat Dasar}

Penelitian ini merupakan penelitian pengembangan buku ajar mata kuliah keterampilan berbicara Bahasa Mandarin, maka secara umum data yang diperlukan adalah informasi tentang materi-materi yang perlu ada pada mata kuliah tersebut. Peneliti menyusun instrumen berdasarkan indikator pembelajaran, dengan mengacu pada kriteria kesesuaian materi dengan standar CEFR dan HSK. Sumber data berasal dari hasil pengisian instrumen analisis kesesuaian materi dengan CEFR dan HSK tersebut.

Analisis materi ajar percakapan diawali dengan penyusunan kompetensi, materi, dan kosakata berdasarkan dokumen kurikulum program studi, standar CEFR dan HSK. Standar CEFR menjadi standar yang akan digunakan oleh setiap program studi kebahasaan pada FBS UNJ. Standar ini digunakan untuk menghadapi hadirnya masa dimana mobilitas dan komunikasi internasional telah sangat intens seperti saat ini, sementara terjadi keberagaman sistem pendidikan antar institusi di setiap negara, dengan keberagaman identitas serta budaya.

Berdasarkan analisis yang dilakukan terhadap kompetensi yang diharapkan, materi, serta kosakata yang sesuai pada setiap mata kuliah keterampilan berbicara semester 1 hingga 4, dapat dilihat pada tabel berikut:

Tabel 5. Draft Materi dan Kosakata Mata Kuliah Keterampilan Berbicara Semester I Hingga IV Berdasarkan CPMK, CEFR dan HSK

\begin{tabular}{|l|l|l|l}
\hline No & $\begin{array}{l}\text { Mata } \\
\text { Kuliah }\end{array}$ & Kompetensi & Materi \\
\hline
\end{tabular}




\begin{tabular}{|c|c|c|c|}
\hline 1. & $\begin{array}{l}\text { Menyimak } \\
\text { dan } \\
\text { Berbicara } \\
\text { Dasar I }\end{array}$ & 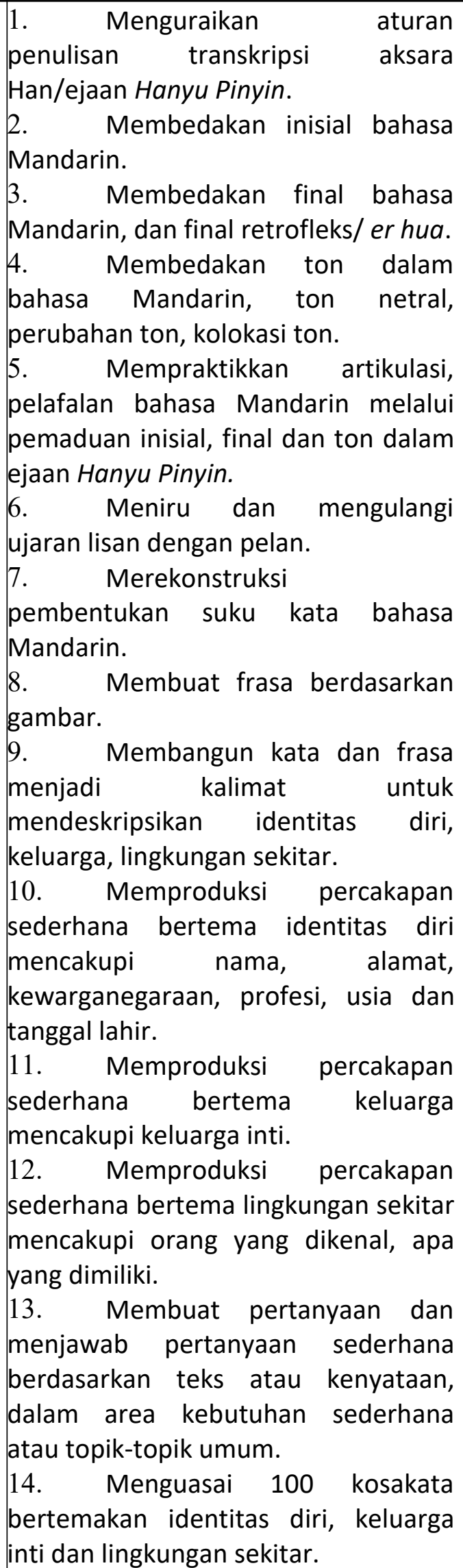 & $\begin{array}{l}\text { 1. Ejaan hanyu pinyin } \\
\text { 2. Inisial, final, ton } \\
\text { 3. Pembentukan suku kata bahasa } \\
\text { Mandarin } \\
\text { 4. Kata, frasa } \\
\text { 5. Menceritakan gambar menjadi } \\
\text { frasa } \\
\text { 6. Menyusun kalimat } \\
\text { 7. Memproduksi dialog sederhana } \\
\text { bertema identitas diri, keluarga, } \\
\text { lingkungan sekitar: } \\
\text { 8. Sapaan } \\
\text { 9. Perkenalan atau informasi diri } \\
\text { (nama, kewarganegaraan, } \\
\text { pekerjaan), keluarga, sekolah, } \\
\text { perusahaan dan pekerjaan } \\
\text { 10. Pelajaran dan } \\
\text { (pengalaman belajar dan } \\
\text { bekerja) } \\
\text { 11. Kegemaran dan keahlian } \\
\text { khusus dan } \\
\text { 12. Makanan (makanan dan } \\
\text { minuman, makan di luar, } \\
\text { kebiasaan makan) } \\
\text { 13. Waktu (hari, tanggal) } \\
\text { 14. Berbelanja (mata uang, satuan } \\
\text { dan ukuran, harga, bahan dan } \\
\text { kualitas, menukar uang) } \\
\text { 15. Berkunjung kebugaran } \\
\text { 16. Kesehatan dan kadan) } \\
\text { (pergi ke dokter, latihan gerak } \\
\text { 17. Keluarga dan } \\
\text { (sebutan, hubungan, ciri fisik) }\end{array}$ \\
\hline 2. & $\begin{array}{l}\text { Menyimak } \\
\text { dan }\end{array}$ & $\begin{array}{l}\text { 1. Menguraikan aturan penulisan } \\
\text { transkripsi aksara Han/ejaan Hanyu }\end{array}$ & $\begin{array}{l}\text { 1. Ejaan hanyu pinyin } \\
\text { 2. Inisial, final, ton }\end{array}$ \\
\hline
\end{tabular}




\begin{tabular}{|c|c|c|}
\hline $\begin{array}{l}\text { Berbicara } \\
\text { Dasar II }\end{array}$ & 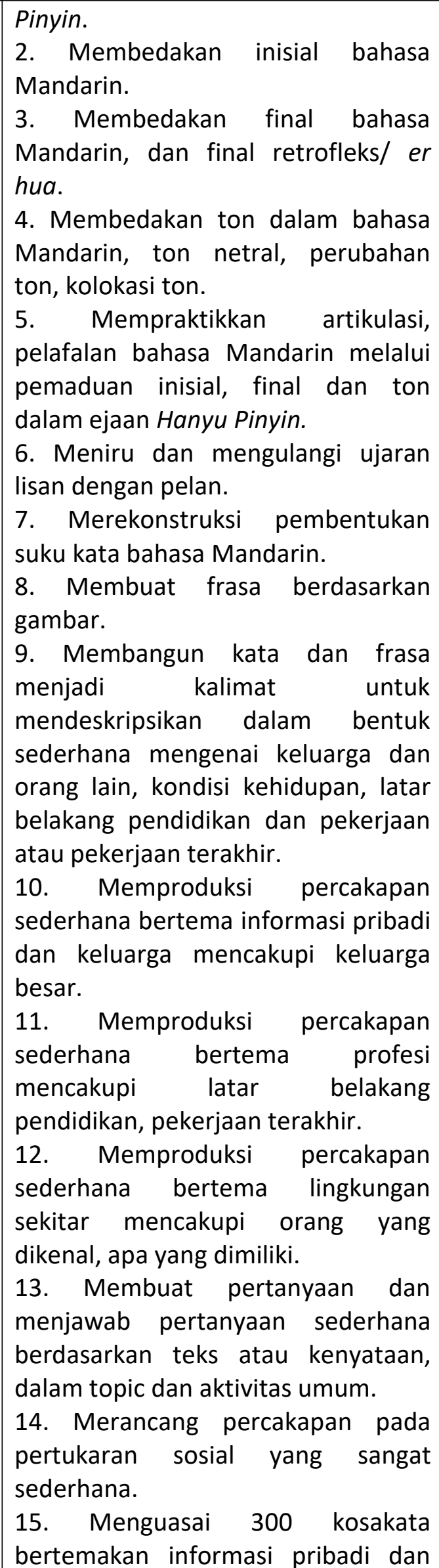 & $\begin{array}{l}\text { 3. Pembentukan suku kata } \\
\text { bahasa Mandarin } \\
\text { 4. Kata, frasa } \\
\text { 5. Menceritakan gambar menjadi } \\
\text { frasa } \\
\text { 6. Menyusun kalimat } \\
\text { 7. Memproduksi dialog sederhana } \\
\text { bertema informasi diri dan } \\
\text { keluarga, kegiatan sehari-hari di } \\
\text { lingkungan sekitar, profesi } \\
\text { 8. Persamaan dan perbedaan } \\
\text { 9. Peristiwa yang sudah terjadi } \\
\text { 10. Peristiwa yang sedang terjadi } \\
\text { 11. Peristiwa yang akan terjadi } \\
\text { 12. Perintah atau ajakan } \\
\text { 13. Pengalaman } \\
\text { 14. Akibat atau hasil dari } \\
\text { peristiwa yang sudah terjadi }\end{array}$ \\
\hline
\end{tabular}




\begin{tabular}{|c|c|c|c|}
\hline & & $\begin{array}{l}\text { keluarga, kegiatan sehari-hari di } \\
\text { lingkungan sekitar dan profesi. }\end{array}$ & \\
\hline 3. & $\begin{array}{l}\text { Menyimak } \\
\text { dan } \\
\text { Berbicara } \\
\text { Dasar III }\end{array}$ & $\begin{array}{l}\text { 1. Mempraktikkan artikulasi, } \\
\text { pelafalan bahasa Mandarin melalui } \\
\text { pemaduan inisial, final dan ton } \\
\text { dalam ejaan Hanyu Pinyin. } \\
\text { 2. Meniru dan mengulangi ujaran } \\
\text { lisan dengan lebih cepat. } \\
\text { 3. Membangun frasa menjadi } \\
\text { kalimat untuk mendeskripsikan } \\
\text { kehidupan sekolah, aktivitas profesi, } \\
\text { kegiatan waktu luang. } \\
\text { 4. Membuat kalimat berdasarkan } \\
\text { gambar. Memproduksi percakapan } \\
5 \text { sederhana bertema aktivitas profesi, } \\
\text { mencakupi aktivitas profesi, } \\
\text { harapan, dan ambisi. } \\
\text { 6. Memproduksi percakapan } \\
\text { sederhana bertema kegiatan waktu } \\
\text { luang mencakupi hobi, pengalaman } \\
\text { yang telah dilakukan sebelumnya, } \\
\text { kegiatan, impian, pendapat, dan } \\
\text { rencana. } \\
\text { 7. Mempraktikkan percakapan tanpa } \\
\text { persiapan pada topik-topik umum, } \\
\text { peminatan individu ataupun yang } \\
\text { berhubungan dengan kehidupan } \\
\text { sehari-hari mencakupi keluarga, } \\
\text { hobi, pekerjaan, pengalaman, dan } \\
\text { kejadian tertentu. } \\
\text { 8. Membangun frasa menjadi } \\
\text { kalimat untuk mendeskripsikan } \\
\text { pengalaman dan kejadian. } \\
9 . \quad \text { Menguraikan alasan dan } \\
\text { penjelasan ringkas mengenai } \\
\text { pendapat dan rencana. } \\
\text { 10. Menyusun jalan cerita dari } \\
\text { sebuah buku atau film dan } \\
\text { menarasikan sebuah cerita. } \\
\text { 11. Menguasai } 600 \text { kosakata } \\
\text { bertemakan kehidupan sekolah, } \\
\text { pekerjaan dan kegiatan waktu luang. }\end{array}$ & $\begin{array}{l}\text { 1. Inisial, final, ton } \\
\text { 2. Pembentukan suku kata } \\
\text { bahasa Mandarin } \\
\text { 3. Frasa } \\
\text { 4. Menceritakan gambar menjadi } \\
\text { kalimat } \\
\text { 5. Menyusun kalimat } \\
\text { 6. Memproduksi dialog sederhana } \\
\text { bertema kehidupan sekolah, } \\
\text { pekerjaan dan kegiatan waktu } \\
\text { luang. } \\
\text { 7. Memperkenalkan diri } \\
\text { 8. Lingkungan sekolah } \\
\text { 9. Lingkungan tempat tinggal } \\
\text { 10. Kesukaan dan hobi } \\
\text { 11. Perbandingan } \\
\text { 12. Perjalanan } \\
\text { 13. Berbelanja }\end{array}$ \\
\hline 4. & $\begin{array}{l}\text { Menyimak } \\
\text { dan } \\
\text { Berbicara }\end{array}$ & $\begin{array}{l}\text { 1. Mempraktikkan artikulasi, } \\
\text { pelafalan bahasa Mandarin melalui } \\
\text { pemaduan inisial, final dan ton }\end{array}$ & $\begin{array}{l}\text { 1. Inisial, final, ton } \\
\text { 2. Pembentukan suku kata } \\
\text { bahasa Mandarin }\end{array}$ \\
\hline
\end{tabular}




\begin{tabular}{|c|c|c|}
\hline Dasar IV & 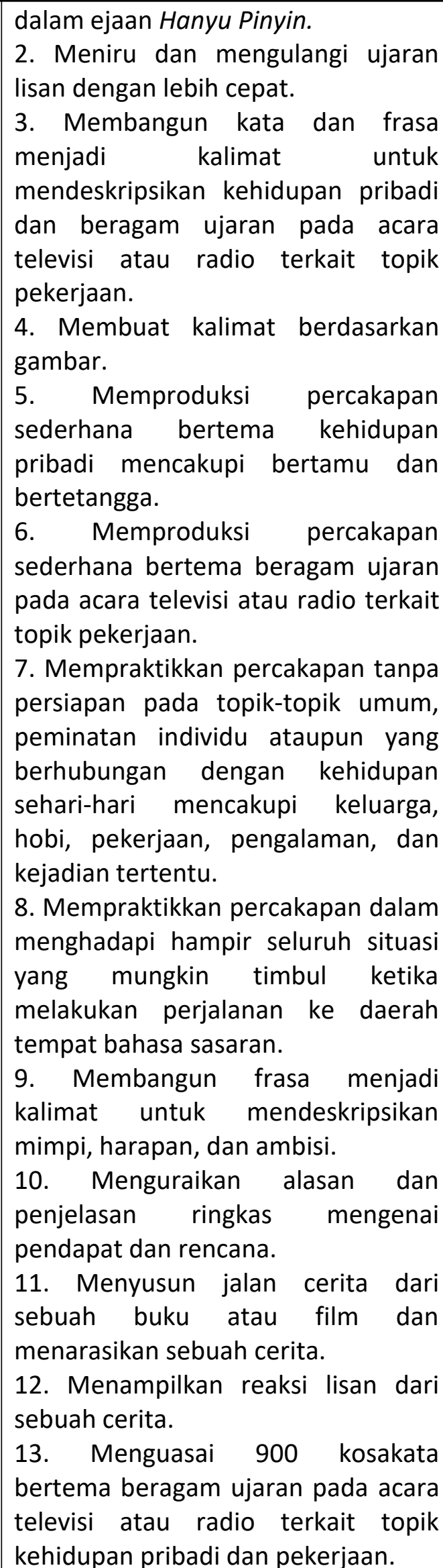 & $\begin{array}{l}\text { 3. Frasa } \\
\text { 4. Menceritakan gambar menjadi } \\
\text { kalimat } \\
\text { 5. Menyusun kalimat } \\
\text { 6. Memproduksi dialog sederhana } \\
\text { bertema beragam ujaran pada } \\
\text { acara televisi atau radio terkait } \\
\text { topik kehidupan pribadi dan } \\
\text { pekerjaan } \\
\text { 7. Bertamu } \\
\text { 8. Bertetangga } \\
\text { 9. Keunikan Cina } \\
\text { 10. Pernikahan } \\
\text { 11. Gender } \\
\text { 12. Kesehatan } \\
\text { 13. Pekerjaan } \\
\text { 14. Keluarga } \\
\text { 15. Pendidikan } \\
\text { 16. Iklan } \\
\text { 17. Internet } \\
\text { 18. Lingkungan } \\
\text { 19. Kebudayaan } \\
\text { 20. Tempat tinggal } \\
\text { 21. Kendaraan }\end{array}$ \\
\hline
\end{tabular}


Selanjutnya peneliti menyusun instrumen penelitian berupa penilaian kesesuaian materi dengan dokumen kurikulum program studi, konsep keilmuan dan standar CEFR serta HSK. Berikut merupakan simpulan dari hasil penilaian terhadap draft materi:

1. Tema dan materi percakapan yang dinilai paling sesuai dengan dokumen kurikulum adalah materi percakapan yang disusun pada mata kuliah Menyimak dan Berbicara Dasar I. Sementara pada mata kuliah lanjutannya, masih harus diperbaiki.

2. Tema percakapan yang disusun pada mata kuliah Menyimak dan Berbicara Dasar II belum bersifat tematik, sehingga kurang sejalan dengan CEFR juga tema-tema pada rangkaian mata kuliah Menyimak dan Berbicara Dasar lainnya.

3. Jenis materi berupa menyusun kata menjadi frasa, menjelaskan gambar, tanya jawab yang mendukung aktivitas berbicara kurang sesuai apabila diberikan pada mata kuliah Menyimak dan Berbicara Dasar IV.

4. Keakuratan runutan penyampaian materi percakapan perlu dikaji kembali.

5. Materi-materi yang sesuai dengan perkembangan jaman perlu ditambahkan.

6. Kemutakhiran dan kebakuan bahasa Mandarin perlu disesuaikan dengan perkembangan bahasa Mandarin saat ini.

7. Jenis latihan lebih bervariasi.

Peneliti juga menyusun draft sistematika buku ajar percakapan. Draft disusun dengan mempertimbangkan komponen yang harus ada pada buku teks serta masukan responden terkait struktur buku ajar Percakapan yang diperoleh pada penelitian Analisis Kebutuhan di tahun 2017 yakni: (1) Perlu adanya kunci jawaban latihan pada seluruh topik latihan, penjelasan kosakata, materi audio, materi muatan sejarah, sumber kutipan, sumber ilustrasi, materi muatan budaya; (2) Perlu memperhatikan hierarki kesulitan latihan; (3) Teks, latihan, contoh penggunaan tata bahasa kurang beragam; (4) Ilustrasi tidak efektif. Penjelasan kosakata bisa pula menggunakan ilustrasi gambar, agar tidak jenuh membacanya; (5) Teks dan latihan pada buku Percakapan untuk tingkat menengah dinilai kurang baik; (6) Perlu diberikan latihan berupa varian situasi, sehingga siswa dapat secara aktif mengembangkan kemampuan berdialog menggunakan bahasa Mandarin.

\section{SIMPULAN}

Berdasarkan paparan pada bagian sebelumnya, penelitian ini telah menjawab pertanyaan penelitian yaitu mengetahui materi percakapan yang diperlukan serta sesuai bagi buku teks untuk keperluan mata kuliah Menyimak dan Berbicara Dasar di PSPBM FBS UNJ.

Melalui penelitian analisis materi dan penyusunan ragangan buku ajar ini, PSPBM mendapatkan produk berupa materi percakapan dan ragangan yang diperlukan untuk kebutuhan penyusunan buku ajar Menyimak dan Berbicara Dasar semester I hingga IV pada Prodi Pendidikan Bahasa Mandarin UNJ. Ragangan tersebut disusun berdasarkan dokumen kurikulum prodi (deskripsi mata kuliah, CPMK), konsep keilmuan, standar CEFR dan HSK.

Hasil penelitian dapat menjadi landasan dalam tahap selanjutnya yaitu penyusunan buku ajar mata kuliah Menyimak dan Berbicara Dasar. 


\section{DAFTAR PUSTAKA}

[1] Cai, Zhengbao. 2009. Hanyu Kouyuke Jiaoxuefa: Shiyong Hanyu Jiaoshi Peixun Jiaocai Xilie. Beijing: BLCU Press.

[2] Richards, Jack C. 2001. Curriculum Development in Language Teaching. Cambridge: Cambridge University Press.

[3] Silaban, B. 2010. Analisis dan Standardisasi Buku Kimia Kelas XII Semester II Berdasarkan Standar Isi KTSP. Tesis Program Pascasarjana UNIMED, 2010.

[4] Tarigan, Henry Guntur. 2013. Berbicara Sebagai Suatu Keterampilan Berbahasa.

Bandung: Penerbit Angkasa.

[5] Trihardini, Ayu dan Aprilia Ruby Wikarti. 2017. Pengembangan Buku Ajar Mata Kuliah Percakapan Prodi Pendidikan Bahasa Mandarin: Analisis Kebutuhan. Laporan Penelitian Fakultas Bahasa dan Seni.

[6] Trihardini, Ayu. 2019. "Revitalisasi Kurikulum Program Studi Pendidikan Bahasa Mandarin

yang Beroreintasi pada Literasi Baru." Makalah dalam Seminar Nasional FFBSI 2019.

[7] Zhang Xiaotao. 2008. "Gaolunbiya Hanyu Kouyu Jiaoxue Diaocha yu Fenxi" dalam Jurnal Jinan Daxue Huawen Xueyuan Xuebao. Vol 4.

[8] Zhao, Jinming. 2008. Hanyu Keyi Zheyang Jiao: Yuyan Jineng Pian. Beijing: Shangwu Yinshuguan.

\section{DATA PENULIS}

$\begin{array}{ll}\text { Nama } & \text { : Ayu Trihardini, M.A. } \\ \text { Program Studi } & \text { : S1 Pendidikan Bahasa Mandarin } \\ \text { Perguruan Tinggi } & : \text { Universitas Negeri Jakarta } \\ \text { Telp. } & \text { : 089636275155 } \\ \text { Email } & \text { : ayu.trihardini@unj.ac.id } \\ & \text { : Aprilia Ruby Wikarti, M.A. } \\ \text { Nama } & \text { : S1 Pendidikan Bahasa Mandarin } \\ \text { Program Studi } & \text { : Universitas Negeri Jakarta } \\ \text { Perguruan Tinggi } & : \text { O8979608797 } \\ \text { Telp. } & : \text { apriliarubyw.s@unj.ac.id } \\ \text { Email } & \text { : Arief Rifki Fadilla } \\ \text { Nama } & : \text { S1 Pendidikan Bahasa Mandarin } \\ \text { Program Studi } & : \text { Universitas Negeri Jakarta } \\ \text { Perguruan Tinggi } & : \text { 0897-5317-314 } \\ \text { Telp. } & : \text { ariefrifkifadilla@gmail.com } \\ \text { Email } & \end{array}$

